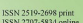

НАУКОВИЙ ВІСНИК

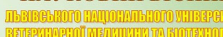

cientific mesenenger of Lviv National University of

(n)

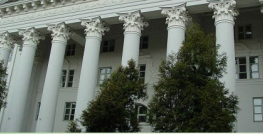

Том 23 № 94 2021
Науковий вісник Дьвівського національного університету ветеринарної медицини та біотехнологій імені С.3. Гжицыкого. Серія: Сільськогосподарські науки

\section{Scientific Messenger of Lviv National University} of Veterinary Medicine and Biotechnologies. Series: Agricultural sciences https://nvlvet.com.ua/index.php/agriculture

UDC 574.64:504.064

\title{
Assessment of microbiological indicators and monitoring of a sociological survey of the quality of sources in the city of Lviv
}

\author{
O. P. Rudenko, N. A. Lytvyn, B. V. Gutyj \\ Stepan Gzhytskyi National University of Veterinary Medicin and Biotechnologies Lviv, Ukraine
}

Article info

Received 18.02.2021

Received in revised form 18.03 .2021

Accepted 19.03.2021

Stepan Gzhytskyi National University of Veterinary Medicine and Biotechnologies Lviv, Pekarska Str., 50, Lviv, 79010, Ukraine.

Tel.: +38-096-813-07-93

E-mail: olgaRudenko86@ukr.net
Rudenko, O. P., Lytvyn, N. A., \& Gutyj, B. V. (2021). Assessment of microbiological indicators and monitoring of a sociological survey of the quality of sources in the city of Lviv. Scientific Messenger of Lviv National University of Veterinary Medicine and Biotechnologies. Series: Agricultural sciences, 23(94), 81-85. doi: 10.32718/nvlvet-a9415

There are a number of springs on the territory of Lviv, water from which is used by the city residents. It should be noted that natural resources cannot be systematically used by the population for drinking purposes, as they are not sources of centralized water supply and, accordingly, do not have service personnel. No sanitary protection zones have been established for such sources, within which economic activities are prohibited. In this regard, the quality of water from such natural sources has unstable indicators, which depend on many factors of man-made and natural factors (sanitary-chemical and sanitary-microbiological indicators can sometimes fluctuate within one week), which makes it unfit for human consumption and can lead to acute intestinal infections of bacterial and viral etiology, a number of infectious diseases. The article considers the current ecological, microbiological state of natural sources of the city of Lviv. The necessity, and hence the relevance of the analysis and detailed microbiological assessment of water quality of springs in the city of Lviv, namely: springs № 1 in the park "Zalizna Voda" (Lviv, Ternopilska Street); springs № 2 in the park "Zalizna Voda" (Lviv, Myshuhy Street); springs № 3 in Stryiskyi Park (Lviv, Stryiska Street). A sociological survey of city residents on the use and consumption of water from the studied sources was conducted. The results of the analysis were compared with the list of maximum concentration limits of harmful substances in water bodies in accordance with the order № 400 from 12.05.2010 on approval of State sanitary norms and rules "Hygienic requirements for drinking water intended for human consumption" (DSanPiN 2.2.4-171-10).

Key words: spring water, groundwater, water resources, water pollution, Zalizna Voda Park, Stryiskyi Park, ecological safety, microbiological indicators.

\section{Оцінка мікробіологічних показників та моніторинг соціологічного опитування якості джерел міста Львова}

\author{
О. П. Руденко, Н. А. Литвин, Б. В. Гутий
}

Львівський національний університет ветеринарної медицини та біотехнологій імені С. 3. Гюицького, м. Львів, Україна

На території м. Львова є низка джерел, вода з яких використовується мешканиями міста. Варто зазначити, щзо природні джерела не можуть систематично використовуватись населенням для питних потреб, оскільки вони не є джерелами иентралізованого водопостачання і відповідно не мають обслуговуючого персоналу. Для таких джерел не встановлені зони санітарної охорони, в межах яких забороняється господарська діяльність. У зв'язку з ичи якість води з таких природніх джерел має нестабільні показники, які залежать від багатьох факторів техногенного та природного характеру (санітарно-хімічні та санітарномікробіологічні показники можуть коливатися інколи протягом одного тижня), цчо робить ї̈ непридатною для споживання людиною і може призвести до виникнення гострих кишкових інфекиій бактеріальної та вірусної етіологї, низки інфекційних захворювань. У статті розглянуто сучасний екологічний, мікробіологічний стан природних джерел міста Львова. Показано необхідність, 
а отже й актуальність аналізу та детальної мікробіологічної оцінки якості води джерел на території м. Львова, а саме: джерела № 1 у парку “Залізна Вода” (м. Львів, вул. Тернопільська); джерела № 2 у парку “Залізна Вода” (м. Львів, вул. Мишуги); джерела № 3 у Стрийському парку (м. Львів, вул. Стрийська). Проведено сочіологічне опитування мешканців міста шиодо використання та споживання води з досліджуваних джерел. Результати аналізу порівнювали з переліком ГДК шкідливих речовин у водних об'єктах згідно з наказом № 400 від 12.05.2010 про затвердження Державних санітарних норм та правил “Гігієнічні вимоги до води питної, призначеної для споживання людиною” (ДСанПіН 2.2.4-171-10).

Ключові слова: джерельна вода, підземні води, водні ресурси, забруднення води, парк “Залізна Вода”, Стрийський парк, екологічна безпека, мікробіологічні показники.

\section{Вступ}

Чиста та доступна вода залишається невід'ємною частиною життєдіяльності людини. Недостатня іï кількість та погана якість, а також нерівноцінний доступ до неї створюють загрози для існування не тільки окремої людини, а й соціуму загалом. Саме на цьому наголошують експерти у сфері сталого розвитку людства до 2030 р., визначаючи, що одним 3 найбільш ефективних інструментів для зміцнення здоров'я і скорочення масштабів зубожіння людства $\epsilon$ забезпечення доступу до безпечного водопостачання (Prokopov \& Ohnianyk, 2016; Kozak \& Kozliuk, 2019; Zorina, 2019).

У сучасних умовах проблема забезпечення населення якісною питною водою стає все більш актуальною. Якість питної води визначається за багатьма факторами: природою джерела, регіональними особливостями грунтових порід і мінералів, ефективністю методів знезараження, ступенем антропогенного навантаження (хімічне або мікробне забруднення) та інші (Avramenko, 2011; Andrusyshyna, 2015; Trahtenberg \& Prodanchuka, 2016).

Для досягнення стійкого доступу до якісної безпечної води та санітарії потрібна взаємодія на всіх рівнях, починаючи від локального впровадження більш ефективних технологій водопостачання та водовідведення і забезпечення належної регуляторної бази. Особливо важливо підвищити рівень обізнаності про механізми водопостачання та водовідведення, проблеми водокористування (Antonova, 2014; Ladychenko, 2015; Lypovetska, 2016; Vytiv, 2018; Kozak \& Kozliuk, 2019; Vodni resursy Ukrainy).

За старих часів існувало повір'я, що, напившись джерельної води, людина здатна почерпнути силу самої землі. Не варто забувати, що джерела мають величезне значення для підтримання водного балансу інших поверхневих джерел. Деякі $з$ джерел являють собою унікальну природну цінність, крім того, це об'єкти пильної уваги вчених, багато 3 них мають значення як пам'ятки природи. До того ж при виникненні надзвичайної ситуації вони - часто єдине джерело питної води (Svirenko et al., 2001; Prymushko et al., 2011; Stepova et al., 2019; Vodni dzherela, 2020).

Відомо, що важливий внесок у добову забезпеченість організму макро- i мікроелементами вносить питна вода. 3 питною водою людина отримує від 8 до $25 \%$ добової потреби мінеральних речовин (Cа - до $20 \%, \mathrm{Mg}-25 \%, \mathrm{~F}-50-80 \%$ до $50 \%$ I). Цим обумовлений i характер біозасвоюваності тих чи інших хімічних елементів організмом людини (Prodanchuk et al., 2006; Khvesyk \& Mandzyk, 2009; Koszisek et al., 2015; Shestopalov \& Ovchynnikova, 2017; Roi, 2017).
Тому метою нашої роботи було проаналізувати та оцінити якість води джерел на території м. Львова, а саме: джерела № 1 у парку “Залізна Вода” (м. Львів, вул. Тернопільська, 6); джерела № 2 у парку “Залізна Вода" (м. Львів, вул. Мишуги); джерела № 3 у Стрийському парку (м. Львів, вул. Стрийська). Ми провели мікробіологічні дослідження та соціологічне опитування мешканців Львова 3 метою підтвердити версію про використання підземних джерельних вод міста для побутових потреб. На основі одержаних результатів запропонували можливі шляхи вирішення безпечного використання джерельних вод міста Львова.

\section{Матеріал і методи досліджень}

Експериментальна частина роботи виконувалась у виробничій лабораторії за адресою: м. Львів вул. Стрийська, 18а. Лабораторія атестована згідно 3 вимогами законодавства, Свідоцтво про атестацію № ПТ- 375/20 від 28.09. 2020 p.

Матеріалом для досліджень слугували проби води 3 трьох джерел міста Львова: № 1 у парку “Залізна Вода" (м. Львів, вул. Тернопільська); № 2 “Залізна Вода" (м. Львів, вул. Мишуги) та № 3 джерело в Стрийському парку (м. Львів, вул. Стрийська).

Відбір проб проводили відповідно до вимог ДСанПіНу N 383/1940 “Вода питна. Гігієнічні вимоги до якості води централізованого господарськопитного водопостачання".

Приготування необхідних розчинів проводилось згідно зі стандартними методиками.

Нами були досліджені мікробіологічні показники: загальне мікробне число, коліформні бактерії та ентерококи.

В проведеному соціологічному опитуванні взяли участь 18 осіб (11 - у Стрийському парку і 7 - у парку “Залізна Вода").

Обробку отриманих результатів здійснено в комп'ютерній програмі Microsoft Excel.

Результати аналізу порівнювали 3 переліком ГДК шкідливих речовин у водних об'єктах згідно з Наказом № 400 від 12.05.2010 про затвердження Державних санітарних норм та правил "Гігієнічні вимоги до води питної, призначеної для споживання людиною" (ДСанПіН 2.2.4-171-10).

\section{Результати та їх обговорення}

На території міста Львова $є$ декілька таких джерел, вода 3 яких використовується мешканцями. У нашій роботі ми дослідили воду з трьох джерел двох парків міста, а саме парку “Залізна Вода” та Стрийського парку. 
Парк “Залізна Вода” - це доволі тихе та популярне місце відпочинку львів'ян. Колись тут були мальовничий ставок Камінського з прозорою водою, буковий ліс і безліч джерел, через високий вміст заліза в яких і виникла назва парку. У вихідні проводилися спектаклі в німецькому літньому театрі, була й корчма.

Стрийський парк (Парк Кілінського) - один із найстаріших та найгарніших парків Львова, пам'ятка садово-паркового мистецтва національного значення. Розташований у місцевості Софіївка Галицького району. Вважався найгарнішим парком міжвоєнної Польщі.

Джерельну воду з досліджуваних парків використовує неабияка кількість міського населення, тому важливо знати, чи є ці води придатними для побутового використання та споживання зокрема.

Мікробіологія води вивчає екологію мікроорганізмів, що живуть у воді, вплив різних токсикантів на мікроорганізми та гідробіонти, мікробіологічне забруднення водойм, морфологію та фізіологію всіх представників мікросвіту (бактерії, гриби, найпростіші, віруси). За своєю суттю мікробіологія води $\epsilon$ фундаментальною наукою для фахівців у сфері очищення води (Chub, 2019). Мікробіологічні показники - показники епідемічної безпеки питної води, перевищення яких може призвести до виникнення інфекційних хвороб у людини (Pro zatverdzhennia Derzhavnykh sanitarnykh norm).

Під час досліджень мікробіологічних показників в усіх досліджуваних джерелах у воді подекуди можна було помітити перевищення чинних норм мікробіологічної безпеки.

Дані про мікробіологічні показники природних джерел міста Львова наведено у таблиці 1.

\section{Таблиця 1}

Визначення мікробіологічних показників природних джерел міста Львова

\begin{tabular}{ccccc}
\hline Джерело & $\begin{array}{c}\text { Загальне мікробне } \\
\text { число, КУО/мл }\end{array}$ & $\begin{array}{c}\text { Коліформні бактерії, } \\
\text { КУО/100 мл }\end{array}$ & E.coli, КУО/ 100 мл & Ентерококи, КУО/мл \\
\hline № 1 & 49 & відсутні & відсутні & відсутні \\
№ 2 & 98 & 3 & 2 & відсутні \\
№ 3 & 71 & 3 & відсутні & відсутні \\
ГДК & $\leq 100$ & $\leq 1$ & відсутні & відсутні \\
\hline
\end{tabular}

Примітка: № 1 - джерело парку “Залізна Вода” (вул. Тернопільська); № 2 - джерело парку “Залізна Вода” (вул. Мишуги); № 3 - джерело в Стрийському парку (вул. Стрийська)

Загальне мікробне число - це показник, що характеризує загальне мікробне зараження. Перевищення даного показника може свідчити про наявність, крім сапрофітної мікробіоти, ще й патогенної. У країнах Європи цей показник допускається до 20 КУО/мл. В Україні ЗМЧ для водопровідної води допускається до 100 КУО/мл, а для джерел та каптажів даний показник не нормується. Усі досліджувані зразки мали показники в межах норми, хоча у другому зразку даний показник був дещо перевищений.

Загальні коліформні бактерії - це мікроорганізми групи кишкової палички. У воду вони потрапляють переважно з фекальними стоками і здатні виживати там протягом декількох тижнів, проте зазвичай у даному середовищі вони і не розмножуються.

Число коліформних бактерій перевищувало допустимі норми у 2 та 3 зразках. У зразках 2 і 3 виявлено однакову кількість коліформних бактерій. А безпосередньо в 2 зразку ідентифіковано 2 КУО E. coli. Наявність коліформних бактерій у воді свідчить про вто- ринне зараження або про наявність надлишкової кількості поживних речовин.

Ентерококи - це бактерії родини Enterococcaceae i належать до санітарно-показових мікроорганізмів. 3 точки зору фізіологічних особливостей вони схожі зі стрептококами. У кишечнику людини широко представлені два види симбіонтів - E. faecalis i E. faecium. Ентерококи були відсутні у всіх досліджуваних зразках.

Ентерококи мають щонайменше 20 видів, що мають екологічне значення і здатні довгий час виживати в грунті і воді. Ці мікроорганізми можуть викликати порушення роботи травної системи і органів, захворювання шкіри, рота, носа, сечостатевих і жовчних шляхів.

У нашій роботі ми провели соціологічне опитування мешканців Львова 3 метою підтвердити версію про використання підземних джерельних вод міста для побутових потреб.

\footnotetext{
На питання: якими джерелами питної води ви користуєтеся?

$\checkmark \quad 16,7 \%$ відповіли, що використовують і водопровідну, і джерельну воду;

$\checkmark \quad 77,8 \%$ відповіли, що використовують водопровідну воду;

$\checkmark \quad 5,5 \%$ відповіли, що використовують джерельну воду.
}

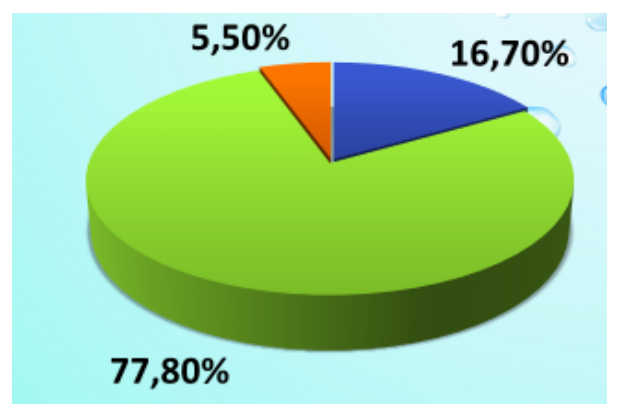


На питання: 3 якою періодичністю ви користуєтеся джсерельною водою?

$\checkmark 25 \%$ відповіли, що використовують воду 1 -

2 рази в тиждень;

$\checkmark 75 \%$ відповіли, що використовують воду 1-

2 рази на місяць.

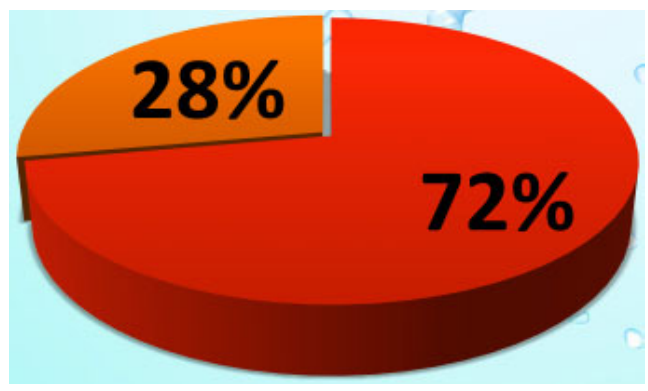

На запитання: які способи очищення питної води ви використовуєте?

$\checkmark$ 33,3\% відповіли, що використовують фільтруючі пристрої;

$\checkmark 44,4 \%$ відповіли, що очищають воду кип'ятінням;

$\checkmark$ 22,3 \% відповіли, що не використовують очистку.

Ми пропонуємо такий підхід до вирішення питань екологічно безпечного використання джерельних вод, який базується на врахуванні екологічних аспектів, структури міської забудови, що склалася, прогнозу міграції техногенних забруднень:

1. Нині якість води джерел м. Львова не гарантує екологічно безпечного іiі використання для питних цілей. Ранжування досліджуваних джерел, а саме: в Стрийському парку (вул. Стрийська) та джерел № 1 i № 2 в парку “Залізна Вода” за адресами - вул. Мишуги та вул. Тернопільська, 6 показало, що залежно від якості води найбільше відповідає питним нормативам вода 3 джерела в Стрийському парку, але й тут мають місце відхилення від нормативів за багатьма показниками.

2. Для того, щоб забезпечити екологічно безпечне використання води джерел у сучасних умовах мегаполісів (наприклад, м. Львова) необхідно виконати комплекс природоохоронних (екологічних), реконструктивних і науково-організаційних заходів:

- постійно контролювати якість води;

- здійснити комплекс заходів щодо гарантованого захисту зон живлення джерел. До виконання цих заходів впровадити режим обмеження використання води джерел, що розташовані в межах міста і не мають гарантованого захисту зон живлення від техногенного забруднення. У м. Львові сказане стосується практично всіх джерел;

- щодо захисту джерельних вод від бактеріального забруднення в місцях виходу джерел розробити інженерні заходи;

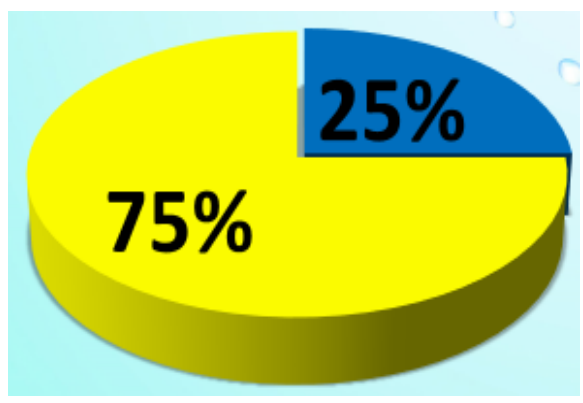

\section{На питання: чи володісте ви достовірними даними про якість води, якою користуєтеся? $\checkmark$ 72,2\% відповіли, що ні; $\checkmark$ 27,8 \% відповіли, що мають деякі відомості.}

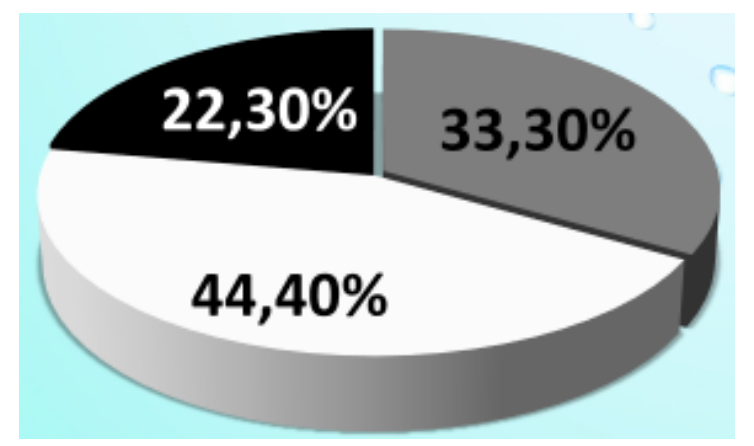

- розробити проєкти і здійснити будівництво біологічної очистки та знезаражування води джерел перед використанням для питних цілей. Проєкти повинні передбачати очистку джерельних вод від надлишку солей, органічних забруднень, нафтопродуктів, сполук групи азоту та інших екологічно небезпечних інгредієнтів, а також знезаражування ультрафіолетовим опроміненням. До реалізації вказаних заходів використовувати воду джерел для питних цілей необхідно в обмеженому обсязі при строгому санітарному контролі.

3. Здійснення вищевказаних заходів дозволить забезпечити екологічно безпечне використання джерельних вод урбанізованих територій для питних цілей.

Запропонована концепція дозволяє вважати джерела, що досліджувалися, одним з резервів водопостачання міста як у звичайні періоди експлуатації, так і особливо в разі екстремальних ситуацій.

Для отримання більш достовірної і повної інформації про екологічний стан окремих джерел м. Львова доцільно в майбутньому провести аналіз грунтів і рослин на території джерел, оскільки дані постійно змінюються й інформація з наявних джерел не завжди відповідає дійсності. Також хочеться сподіватися на дії органів державної влади й на підвищення рівня культури та екологічної освіти населення, що $є$ важливою частиною у захисті навколишнього середовища і природоохоронній діяльності. 


\section{Висновки}

1. Санітарний стан вивчених джерел не відповідає санітарно-гігієнічним нормам. На території джерела в парку “Залізна Вода” на вулиці Мишуги ми виявили значне забруднення;

2. Вода із усіх досліджуваних джерел містила велику кількість мікроорганізмів, що перевищувало допустимі значення.

3. На думку 95 \% (тобто практично всіх опитаних), є необхідність законодавчого супроводу забезпечення якості питної води. Люди переконані, що пересічний громадянин обов'язково повинен мати постійний доступ до інформації про якість води, яку він вживає.

\section{References}

Andrusyshyna, I. M. (2015). Vplyv mineralnoho skladu pytnoi vody na stan zdorovia naselennia. Voda i vodoochysni tekhnolohii. Naukovo-tekhnichni visti, 22-31 (in Ukrainian).

Antonova, S. Ye. (2014). Orhanizatsiino-pravove zabezpechennia $\mathrm{v}$ sferi derzhavnoho upravlinnia vodozabezpechennia naselennia. Derzhavne upravlinnia: udoskonalennia ta rozvytok, 5. URL: http://www.dy.nayka.com.ua/?op=1\&z=718

(in Ukrainian).

Avramenko, L. M. (2011). Zabezpechennia naselennia yakisnoiu i bezpechnoiu pytnoiu vodoiu - priorytetne zavdannia okhorony zdorovia. Skhidnoievropeiskyi zhurnal hromadskoho zdorovia, 1, 53-55 (in Ukrainian).

Chub, I. M. (2019). Metodychni rekomendatsii do orhanizatsii samostiinoi roboty, vykonannia laboratornykh robit ta provedennia praktychnykh zaniat iz dystsypliny "Mikrobiolohiia i khimiia vody" (dlia studentiv 1-2 kursiv dennoi i zaochnoi form navchannia haluzi znan 19 - Arkhitektura ta budivnytstvo, spetsialnosti 192 Budivnytstvo ta tsyvilna inzheneriia spetsializatsiia (osvitnia prohrama) "Hidrotekhnika" (Vodni resursy). KhNUMH im. O. M. Beketova (in Ukrainian).

Khvesyk, M. A., \& Mandzyk, V. M. (2009). Vodni resursy - investytsiia sohodennia i perspektyva maibutnoho. Investytsii: praktyka ta dosvid, 1, 2-8. URL: http://nbuv.gov.ua/UJRN/ipd_2009_1_2 (in Ukrainian).

Koszisek, F., Rosborg, I., Selinus, O., Ferrante, M., \& Jovanonic, D. (2015). Drinking water minerals and mineral balance. SIP, Switzerland.

Kozak, V. I., \& Kozliuk, O. O. (2019). Rozrobka haluzevykh stratehii ta prohram vodopostachannia, vodovidvedennia ta sanitarii $\mathrm{V}$ obiednanykh terytorialnykh hromadakh: metodychnyi posibnyk. K.: DESPRO (in Ukrainian).

Ladychenko, V. V. (2015). Mistse prava na pytnu vodu V systemi prav liudyny. Naukovi zapysky Mizhnarodnoho humanitarnoho universytetu: [zbirnyk]. Odesa: Feniks, 23, 62-65. URL: http://www.scinotes.mgu.od.ua/archive/v23/27.pdf (in Ukrainian).

Lypovetska, O. B. (2016). Vplyv dovhotryvaloho spozhyvannia nekondytsiinoi za mineralnym skladom pytnoi vody na formuvannia neinfektsiinoi zakhvoriuvanosti naselennia ta rozrobka profilaktychnykh zakhodiv: avtoref.. dys. ... kand. med. nauk. Kyiv (in Ukrainian).

Pro zatverdzhennia Derzhavnykh sanitarnykh norm ta pravyl "Hihiienichni vymohy do vody pytnoi, pryznache-noi dlia spozhyvannia liudynoiu" (dsanpin 2.2.4-171-10) URL: https://zakon.rada.gov.ua/laws/ show/z0452-10\#text (in Ukrainian).

Prodanchuk, M. H., Mudryi, I. V., \& Velykyi, V. I. (2006). Naukovo-metodychni aspekty toksykolohoklinichnykh do-slidzhen vplyvu mineralnoho skladu pytnoi vody na stan zdorovia naselennia Ukrainy. Sovremennye problemy toksykolohii, 3, 4-7. URL: https://scholar.google.com/scholar?cluster=119396022 27861470078\&hl=en\&oi=scholarr (in Ukrainian).

Prokopov, V. O., \& Ohnianyk, N. S. (2016). Pytna voda Ukrainy: medyko-ekolohichni ta sanitarnohihiienichni aspekty. Medytsyna. Kyiv (in Ukrainian).

Prymushko, S. I. Biloshapskoi, T. D., \& Velychko, V. F. (2011). Stan pidzemnykh vod Ukrainy: shchorichnyk. Kyiv: Derzhavne naukovo-vyrobnyche pidpryiemstvo "Derzhavnyi informatsiinyi heolohichnyi fond Ukrainy" (in Ukrainian).

Roi, I. O. (2017). Pidvyshchennia ekolohichnoi bezpeky pytnoho vodopostachannia shliakhom intensyfikatsii protsesu okyslennia orhanichnykh rechovyn : avtoref. dys. ... kand. tekh. nauk. Sumy (in Ukrainian).

Shestopalov, V. M., \& Ovchynnikova, N. B. (2017). Doslidzhennia rivnovazhnoho stanu vody ta problema vplyvu pytnoi ta mineralnoi vody na zdorovia liudyny. Heolohichnyi zhurnal, 1, 23-36. URL: http://nbuv.gov.ua/UJRN/geojur_2017_1_4 (in Ukrainian).

Stepova, K. V., Musii, K. P., \& Dumas, I. Z. (2019). Otsinka yakosti vody u pryrodnykh dzherelakh $\mathrm{m}$. Lvova. Visnyk Lvivskoho derzhavnoho universytetu bezpeky zhyttiediialnosti, 20, 106-109. doi: 10.32447/20784643.20.2019.16 (in Ukrainian).

Svirenko, L. P. Spirin, O. I., \& Yakovliev, V. V. (2001). Pidzemni vody urbanizovanykh terytorii ta poviazani $\mathrm{z}$ nymy problemy. Kommunal. khoz-vo horodov : nauch.tekhn. sb. K.: Tekhnika, 36, 186-189 (in Ukrainian).

Trahtenberg, I. M., \& Prodanchuka, N. G. (2016). Populjarnaja toksikologija. K.: VD "Avicena" (in Russian).

Vodni dzherela (2020). URL: https://buvrzt.gov.ua/dzerelo. html (in Ukrainian).

Vodni resursy Ukrainy. URL: http://www.nbuv.gov.ua/ node/3972 (in Ukrainian).

Vytiv, V. A. (2018). Pravove rehuliuvannia yakosti i bezpeky pytnoi vody $\mathrm{v}$ YeS ta Ukraini. Molodyi vchenyi, 12(64), 175-178. URL: http://nbuv.gov.ua/UJRN/molv_2018_12\%281\%29 47 (in Ukrainian).

Zorina, O. V. (2019). Hihiienichni problemy pytnoho vodopostachannia Ukrainy ta shliakhy yikh vyrishennia v umovakh yevrointehratsii: avtoref. dys. ... d- ra biol. nauk: Kyiv (in Ukrainian). 